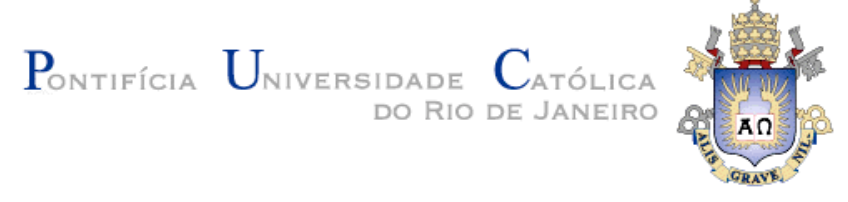

Thiago Ribeiro Nunes

\title{
A Model for Exploration of Semi-Structured Datasets
}

TESE DE DOUTORADO

Thesis presented to the Programa de Pós-Graduação em Informática of the Departamento de Informática, PUC-Rio as partial fulfillment of the requirements for the degree of Doutor em Ciências - Informática

Advisor: Prof. Daniel Schwabe 


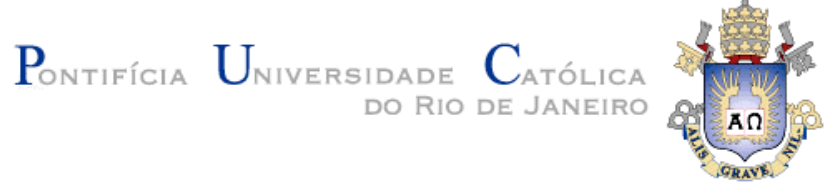

Thiago Ribeiro Nunes

\section{A Model for Exploration of Semi-Structured Datasets}

Thesis presented to the Programa de Pós-Graduação em Informática of PUC-Rio in partial fulfillment of the requirements for the degree of Doutor em Ciências - Informática. Approved by the undersigned Examination Committee.

Prof. Daniel Schwabe

Advisor

Departamento de Informática - PUC-Rio

Prof ${ }^{a}$. Adriana Pereira de Medeiros Universidade Federal Fluminense - UFF

Prof. Edward Hermann Haeusler Departamento de Informática - PUC-Rio

Prof. Hélio Côrtes Vieira Lopes Departamento de Informática - PUC-Rio

Prof ${ }^{a}$. Maria Luiza Machado Campos Universidade Federal do Rio de Janeiro - UFRJ

Prof. Sergio Lifschitz Departamento de Informática - PUC-Rio

Prof. Márcio da Silveira Carvalho

Vice Dean of Graduate Studies Centro Técnico Científico da PUC-Rio 
All rights reserved.

Thiago Ribeiro Nunes

Graduated in Computer Science from Universidade Cândido Mendes UCAM in 2009, he obtained the degree of Doutor at PUC-Rio in 2017 in Ciências - Informática in 2017

Bibliographic data

Nunes, Thiago Ribeiro

A model for exploration of semi-structured datasets / Thiago Ribeiro Nunes ; advisor: Daniel Schwabe. - 2017.

144 f. : il. ; $30 \mathrm{~cm}$

Tese (doutorado)-Pontifícia Universidade Católica do Rio de Janeiro, Departamento de Informática, 2017.

Inclui bibliografia

1. Informática - Teses. 2. Exploração. 3. Modelo formal. 4. Framework. 5. Dados semiestruturados. I. Schwabe, Daniel. II. Pontifícia Universidade Católica do Rio de Janeiro. Departamento de Informática. III. Título. 


\section{Acknowledgments}

To God and Jesus Christ: my endless source of life inspiration, piece, and love.

I would like to express my sincere gratitude to my advisor Prof. Daniel Schwabe for the continuous support of my Ph.D study and research, for his patience, motivation, enthusiasm, friendship, and all knowledge and experience shared. His advices helped me in all the time of research and writing of this thesis.

Besides my advisor, I would like to thank my thesis committee: Prof ${ }^{\mathrm{a}}$. Adriana Pereira de Medeiros, Prof. Antonio Luiz Furtado, Prof. Edward Hermann Haeusler, Prof. Hélio Côrtes Vieira Lopes, Prof ${ }^{a}$. Maria Luiza Machado Campos, Prof. Mark Douglas de Azevedo Jacyntho, and Prof. Sergio Lifschitz, for their availability and insightful comments.

I would like to thank all Departamento de Informática (DI) staff, for the support along this journey.

To Instituto Federal Fluminense, CAPES, CNPq, and Google Brazil Research Program for the financial support along this research project.

To my colleagues at TecWeb Lab, especially to Guilherme Szundy, for the technical support along this research.

To my wife Camila Botelho da Silva, for all emotional support, love, and motivation she gave me along this research, essential for my success.

To my parents Iva Rangel Ribeiro Nunes and Reginaldo Soares Nunes, for the unconditional love, education, values, motivation, and support they gave me throughout my life.

To my family, for the encouraging words, kindness, and emotional support in the difficult moments.

To my friends: Chrystiano Araújo, Marcelo Arruda, Leandro Cruz, José Eduardo Talavera Herrera, and Ana Laura Tavares Rodrigues, for the nice moments, encouraging words, and motivation.

And finally, last but by no means least, to my friends at Instituto Federal Fluminense campus Campos-Guarus for the support along this research. 


\section{Abstract}

Nunes, Thiago Ribeiro; Schwabe, Daniel (Advisor). A Model for Exploration of Semi-Structured Datasets, Rio de Janeiro, 2017. 144p. Tese de Doutorado - Departamento de Informática, Pontifícia Universidade Católica do Rio de Janeiro.

Information exploration processes are usually recognized by their inherent complexity, lack of knowledge and uncertainty, concerning both the domain and the solution strategies. Even though there has been much work on the development of computational systems supporting exploration tasks, such as faceted search and set-oriented interfaces, the lack of a formal understanding of the exploration process and the absence of a proper separation of concerns approach in the design phase is the cause of many expressivity issues and serious limitations. This work proposes a novel design approach of exploration tools based on a formal framework for representing exploration actions and processes. Moreover, we present a new exploration system that generalizes the majority of the state-of-the art exploration tools. The evaluation of the proposed framework is guided by case studies and comparisons with state-of-the-art tools. The results show the relevance of our approach both for the design of new exploration tools with higher expressiveness, and formal assessments and comparisons between different tools.

\section{Keywords}

Exploration; Formal Model; Framework; Semi-Structured Data 


\section{Resumo}

Nunes, Thiago Ribeiro; Schwabe, Daniel (Advisor). Um Modelo para Exploração de Dados Semiestruturados. Rio de Janeiro, 2017. 144p. Tese de Doutorado - Departamento de Informática, Pontifícia Universidade Católica do Rio de Janeiro.

Tarefas de exploração de informação são reconhecidas por possuir características tais como alta complexidade, falta de conhecimento do usuário sobre o domínio da tarefa e incertezas sobre as estratégias de solução. O estadoda-arte em exploração de dados inclui uma variedade de modelos e ferramentas baseadas em diferentes paradigmas de interação, como por exemplo, busca por palavras-chave, busca facetada e orientação-a-conjuntos. Não obstante os muitos avanços das últimas décadas, a falta de uma abordagem formal do processo de exploração, juntamente com a falta de uma adoção mais pragmática do princípio de separação-de-responsabilidades no design dessas ferramentas são a causa de muitas limitações. Dentre as limitações, essa tese aborda a falta de expressividade, caracterizada por restrições na gama de estratégias de solução possíveis, e dificuldades de análise e comparação entre as ferramentas propostas. A partir desta observação, o presente trabalho propõe um modelo formal de ações e processos de exploração, uma nova abordagem para o projeto de ferramentas de exploração e uma ferramenta que generaliza o estado-da-arte em exploração de informação. As avaliações do modelo, realizadas por meio de estudos de caso, análises e comparações o estado-da-arte, corroboram a utilidade da abordagem.

\section{Keywords}

Exploração; Modelo Formal; Framework; Dados Semiestrutrados 


\section{Summary}

1 Introduction 12

1.1. Research Questions 14

1.2. Research Goals and Methodology 15

2 Information Exploration $\quad 17$

2.3. Summary 28

3 A Framework of Reference $\quad 30$

3.1. Functional Layer 35

3.2. Interaction/Interface 37

3.3. Data Model 40

3.4. Related Works 42

4 Functional Layer of Exploration Framework 44

4.1. Preliminary notations 44

4.2. The Exploration Process 45

4.3. Data Model 46

4.3.1. Dataset, Items, and Relations 47

4.3.2. Exploration Sets and Exploration Items 50

4.4. A Model of Exploration Operations 52

4.4.1. Notational Convention for Functions 52

4.4.2. Extension-Oriented Operations 53

$\begin{array}{ll}\text { 4.5. Reusing Explorations } & 69\end{array}$

5 Case Study Evaluations $\quad 74$

5.1. Case Study 1: Discovering Technological Trends 74

5.1.1. Task Execution $\quad 75$

5.1.2. Alternative Strategies $\quad 77$

5.1.3. Generalizing and Reusing Exploration Patterns 79

5.2. Case Study 2: Evaluating a scientific paper 80 
5.3. Case Study 3: Summarizing Gene Clusters 84

5.4. Alternative Strategy 88

5.4.1. Generalization and Reuse 89

5.5. Conclusions 89

6 Evaluation of Exploration Tools 91

6.1. Tactical Analysis 91

6.2. Strategic Analysis 99

6.2.1. Notational Conventions 100

6.2.2. Evaluation 102

6.3. Evaluating Business Intelligence and Visualization tools 107

7 Design Issues and Implementation 113

7.1. Functional Layer 113

7.2. Interaction/Interface Design 115

7.2.1. Requirement 1: Manipulation of Exploration Sets and Items 115

7.2.2. Requirement 2: Applying Exploration Operations 122

7.2.3. Requirement 3: Exploration trail management and browsing 129

8 Conclusions and Future Works 133

9 References 136

$\begin{array}{ll}\text { Attachement A } & 143\end{array}$ 


\section{List of Images}

Figure 1 - Information Retrieval model (BATES, 1989) 18

Figure 2 - Wilson's Model of Information Seeking (WILSON, T.D., 1999) 23

Figure 3 - Bate's Berrypicking Model (BATES, 1989) 24

Figure 4 - Marchionini's Exploratory Search Model (MARCHIONINI, 2006) 26

Figure 5 - Norman's execution and evaluation gulfs

(NORMAN; DRAPER, 1986)

Figure 6 - Semantic and articulatory distances for gulf traversals

(NORMAN; DRAPER, 1986)

Figure 7 - The layers of an exploration environment architecture. 34

Figure 8 - gfacet screenshot $\quad 39$

Figure 9 - Rhizomer screenshot presenting the filtering relations as facets and the pivoting controls (GARCÍA et al., 2013)

Figure 10 - Nesting of papers by author by publication year.

Figure 11 - Relation tree representing publication-author relationships

Figure 12 - An exploration set and a path pattern containing the filters for each level.

Figure 13 - Representation of a horizontal mapping in the third level

Figure 14 - Path example that correlates the Senator Christopher Bond with the state of Missouri in Gov.Track.Us dataset (ARAUJO et al., 2010)

Figure 15 - Abstract path pattern that can be generated by a VerticalMap (ARAUJO et al., 2010)

Figure 16 - Exploration graph for finding research areas in common between researchers affiliated to PUC-Rio and UFRJ with reevaluation ordering.

Figure 17 - Patents dataset summarized schema

Figure 18 - Open citations summarized schema $\quad 81$

Figure 19 - Schema of a gene dataset $\quad 86$

Figure 20 - Tactical Analysis Tree $\quad 92$

Figure 21 - pivot and refine in gfacet (HEIM; ZIEGLER; LOHMANN, 2008) 93

Figure 22 - gfacet tactical map $\quad 94$

Figure 23 - (A) Refinement of items by type and relations (movies by 
Title, Year, Director, or Genre). (B) Refined movies and relations presented in a tabular format. 96

Figure 24 - Movies table expanded with theaters and restaurants 96

Figure 25 - Tactical map of SeCo 96

Figure 26 - Tactical map of faceted search tools 98

$\begin{array}{ll}\text { Figure } 27 \text { - Independent refinement executions. } & 101\end{array}$

$\begin{array}{ll}\text { Figure 28 - Tableau's main screen } & 108\end{array}$

Figure 29 - Tableau's initial table view presenting the table Person (A);

A join between the tables Person and OrgPerson. 109

Figure 30 - Filters definition view in Tableau 109

$\begin{array}{ll}\text { Figure } 31 \text { - Tableau's tactical map } & 110\end{array}$

Figure 32 - DSL representation of the solution strategy for the paper review case study presented in chapter 5 , section 2

Figure 33 - The interface of the XPlain environment. (A) keyword search

controls; (B) Exploration operations toolbar; (C) Exploration sets area; (D)

Exploration trail view.

Figure 34 - Visor screenshot (POPOV et al., 2011) 118

Figure 35 - Tabular view of Liquid Query (BOZZON, ALESSANDRO et al., 2010)

Figure 36 - Rhizomer list view $\quad 119$

Figure 37 - /facet multilevel list view 119

Figure 38 - Visual representation of an exploration set as a nesting of items and relations.

Figure 39 - Xplain's view for the Refine operation. The user selects relations (A) or relation paths (B) and restriction values for each filter.

Filters can be disjunctive or conjunctive according to the selected logical operator.

Figure 40 - Example of MoLIC diagram for the task of buying a ticket

Figure 41 - (A) Pivot and Refine operations in a single scene; (B) Pivot operation defined in a different interaction scene.

Figure 42 - XPlain interaction dialogue for combinations of Pivot and

Refine

Figure 43 - Linear implementations of Parallax (A) (HUYNH; 
KARGER, 2009) and /facet (B) (HILDEBRAND; OSSENBRUGGEN;

HARDMAN, 2006), and tree view of Sewelis (C) (FERRÉ; HERMANN, 2012)

Figure 44 - Graph representation of the functional composition for the task

"finding relevant and not cited papers". 